\title{
Isolation of an Anti-Cancer Asperuloside from Hedyotis corymbosa L.
}

\begin{abstract}
Nina Artanti ${ }^{1}$, Muhammad Hanafi ${ }^{1^{*}}$, Rina Andriyani ${ }^{1}$, Vienna Saraswati ${ }^{1}$, Zalinar Udin ${ }^{1}$, Puspa D. Lotulung ${ }^{1}$, Ken Ichi Fujita ${ }^{2}$ Yoshinosuke Usuki ${ }^{2}$
\end{abstract}

${ }^{1}$ Research Center for Chemistry, Indonesian Institute of Sciences, Kawasan PUSPIPTEK, Serpong Tangerang-Indonesia 13514/ Jl. Cisitu-Sangkuriang, Gedung 50, Bandung, Indonesia 40135

${ }^{2}$ Material Sciences, Faculty of Science, Osaka City University, Japan

\section{ABSTRACT}

Hedyotis corymbosa L., with local name rumput mutiara, is an anti-inflammatory, anti-cancer and hepatoprotective traditional medicine. The ethanol extract of $H$. corymbosa $L$. shows inhibitory activity to human YMB-1 breast cancer cell line with an $\mathrm{IC}_{50}$ of $6.51 \mu \mathrm{g} / \mathrm{mL}$. The methylene chloride fraction shows a potential cytotoxic activity with an $\mathrm{IC}_{50}$ of $2.75 \mu \mathrm{g} / \mathrm{mL}$. To obtain a lead compound, the extract was further purified by column chromatography. A pure compound is obtained which shows inhibitory activities against YMB-1, HL60 and $\mathrm{KB}$ human cell lines with $\mathrm{IC}_{50}$ values of $0.7 ; 11.0$ and $104.2 \mu \mathrm{g} / \mathrm{mL}$, respectively. Based on the 1D and 2D FTNMR data, the isolated compound is an asperuloside.

Keywords: asperuloside, Hedyotis corymbosa, HL60, KB, leaf, Rubiaceae, YMB-1

\section{INTRODUCTION}

Hedyotis corymbosa L., with local name rumput mutiara, is one of the herbal medicines used by Indonesian people to treat diseases or to maintain their health [1]. It is also being used to treat inflammation, hepatitis, cancer. There are a wide variety of products from $H$. corymbosa that have been sold for a long period of history [2].

$H$. corymbosa is one of the species from Hedyotis (genus), Rubiaceae (family), Rubiales (ordo), Dicotyledoneae (class), Angiospermae (sub-division), and Spermatophyta (Division). It grows well in dry and sandy soil, along rivers and coasts and in the forests [3-5]. They widely grow in Indonesia, are also found in Malaysia and India. Previous studies on some Hedyotis species have yielded indole alkaloids, anthraquinones, lignans, triterpenes, flavonoids as well as iridoids. the three new iridoid glycosides are identified as hedycorysides A-C [6].

Many Hedyotis species (Rubiaceae) are also used in traditional Chinese medicine (TCM) for the treatment of appendicitis, tonsillitis, hepatitis, dysentery, snake bites, and bruising [7]. The chemical constituents of

*Corresponding author:

Muhammad Hanafi

Research Center for Chemistry,

Indonesian Institute of Sciences, Indonesia

E-mail: hanafi124@yahoo.com this genus include iridoid glycosides, triterpenoids, flavonoids, anthraquinones, coumarins, lignans, and alkaloids, some compounds exerting anti-inflammatory, neuroprotective, and cytotoxic effects [8]. H. corymbosa (Linn.) Lam. is an annual herb widely distributed in the southeast and southwest of China [5]. The whole plant is applied in the clinic against malaria, intestinal abscess, boils, scald, and some kinds of tumors, such as gastric, esophageal, and colorectal carcinomas [9-11].

Investigations on the methanol extract of $H$. corymbosa reveal various bioactivities, namely antibacterial, anti-inflammatory, free radical-scavenging, cytotoxic, and hepatoprotective $[3,12]$. In this investigation, we investigate the cytotoxity of ethanol extract from the whole plant, its fractions and a lead compound of H. corymbosa. We use Sulforhodamine B method against YMB-1, HL60, and KB cell lines to determine the half maximal inhibitory concentration $\left(\mathrm{IC}_{50}\right)$. Based on the active fraction, we have isolated a cytotoxic

Table 1. Cytotoxicity of compound $\mathbf{1}$ (asperuloside) and antimycin $\mathrm{A} 3$

\begin{tabular}{lccc}
\hline & \multicolumn{3}{c}{ IC $_{\text {se }}(\mu \mathrm{g} / \mathrm{mL})$} \\
\cline { 2 - 4 } Compound & YMB-1 & HL60 & KB \\
\hline Asperuloside (1) & 0.7 & 11.0 & 104.2 \\
Antimycin A3 & 0.3 & 1.7 & 2.9 \\
\hline
\end{tabular}


Table 2. ${ }^{1} \mathrm{H}$ and ${ }^{13} \mathrm{C}$-NMR spectral for compound $\mathbf{1}$ and asperuloside

\begin{tabular}{|c|c|c|c|c|}
\hline \multirow{2}{*}{ No } & \multicolumn{2}{|c|}{1 (CD, OD, $300 \mathrm{MHz})$} & \multicolumn{2}{|c|}{ Asperuloside ( $\left(\mathrm{CD}_{3} \mathrm{OD}, 400 \mathrm{MHz}\right)$ [16] } \\
\hline & $\delta_{n}(\mathrm{~m}, \mathrm{~J} \mathrm{~Hz})$ & $\delta_{c}$ & $\delta_{\mathrm{n}}(\mathrm{m}, \mathrm{J} \mathrm{Hz})$ & $\delta_{c}$ \\
\hline 1 & $5.92(d, 2)$ & 100.1 & $5.63(d, 2)$ & 99.9 \\
\hline \multicolumn{5}{|l|}{2} \\
\hline 3 & $7.21(\mathrm{~d}, 2)$ & 150.3 & $7.21(\mathrm{~d}, 2)$ & 150.3 \\
\hline 4 & & 106.3 & & 106.2 \\
\hline 5 & $3.57(\mathrm{~m})$ & 37.5 & $3.21(\mathrm{~m})$ & 37.4 \\
\hline 6 & $5.47(\mathrm{dd}, 1.5 ; 6.8)$ & 86.4 & $5.47(\mathrm{~d}, 6.8)$ & 86.3 \\
\hline 7 & $5.86(d .1 .5)$ & 129.0 & $5.86(\mathrm{~m})$ & 128.9 \\
\hline 8 & & 144.1 & & 144.3 \\
\hline 9 & $3.51(\mathrm{~m})$ & 45.3 & $3.55(\mathrm{~m})$ & 45.2 \\
\hline 10 & $4.58(\mathrm{dd}, 12.3 ; 7.8)$ & 64.4 & $4.58(\mathrm{br} \mathrm{s})$ & 64.4 \\
\hline $1^{\prime}$ & $4.6(d, 7.8)$ & 93.4 & $4.96(d, 7.5)$ & 93.3 \\
\hline $2^{\prime}$ & $3.6(\mathrm{~m})$ & 77.9 & & 77.9 \\
\hline $3^{\prime}$ & $3.22(\mathrm{~m})$ & 78.4 & & 78.4 \\
\hline $4^{\prime}$ & $3.3(t, 7.0)$ & 71.6 & & 71.6 \\
\hline $5^{\prime}$ & $3.4(\mathrm{dd}, 7.0 ; 4.8)$ & 74.7 & & 73.8 \\
\hline \multirow[t]{2}{*}{$6^{\circ}$} & $3.82(\mathrm{dd}, 12 ; 2.1)$ & 61.9 & & 61.9 \\
\hline & $3.41(\mathrm{dd}, 12 ; 3.8)$ & & & \\
\hline$-C=0$ & & 172.3 & & 172.3 \\
\hline $\mathrm{CH}_{3} \mathrm{CO}-$ & $2.0(s)$ & 172.6 & $1.98(\mathrm{~s})$ & 172.6 \\
\hline
\end{tabular}

compound and identified its structure.

\section{MATERIALS AND METHODS}

\section{Materials}

Hedyotis corymbosa samples were collected from Indonesian Medicinal and Aromatic Crops Research Institute. Species identification of the species was performed by the Research Center for Biology, Indonesian Institute of Sciences (Cibinong, Indonesia). Whole plant samples were washed and powder dried. The crude extract was obtained using technical grade ethanol as a solvent. Extracts were also obtained with $n$-hexane, methylene chloride, and ethyl acetate as solvents.

\section{Isolation and Identification of Methylene chloride Fraction}

The entire $H$. corymbosa was used in this study. Ethanol extract was dissolved in methanol-water and fractionated in $n$-hexane, methylene chloride, and ethyl acetate. The active methylene chloride (MTC) fraction was purified by column chromatography and crystallized in dichloromethane- $n$-hexane. A pure compound was identified by one dimentional (1D) and 2D (HSQC and HMBC) FT-NMR (Bruker $300 \mathrm{MHz}$ ).

\section{Cell Culturing}

YMB-1 (breast cancer), HL60 and KB cell lines were obtained from Department of Material Science, Faculty of Science-Osaka City University, OsakaJapan. The cell lines were cultivated at $37^{\circ} \mathrm{C}$ with $5 \%$ $\mathrm{CO}_{2}$ in RPMI60 or DMEM (GIBCO) medium supple- mented with 10\% v/v Fetal Bovine Serum (Sigma), 1\% antibiotic-antimycotic (GIBCO).

\section{Assay for Cytotoxic Activity}

The cytotoxic assay was determined using Sulforhodamine B (SRB) method (reference- is this provided by a kit). Cell suspensions $\left(10^{4}\right.$ cells $\left./ \mathrm{mL}\right)$ were seeding to each well and the cells were incubated for at $37^{\circ} \mathrm{C}$ under $5 \% \mathrm{CO}_{2}$. After $24 \mathrm{~h}$, medium was replaced and extracts were added at final concentrations ranging from 100 to $3.125 \mu \mathrm{g} / \mathrm{mL}$. After 24 hours, cold 50\% trichloroacetic acid was added and the plates were incubated at $4^{\circ} \mathrm{C}$ for 30 minutes, washed with tap water 5 times, and air-dried. The wells were incubated with $100 \mu \mathrm{g}$ of SRB dye dissolved in $1 \%$ acetic acid. After rinsing-off unbound dye with $1 \%$ acetic acid five times,

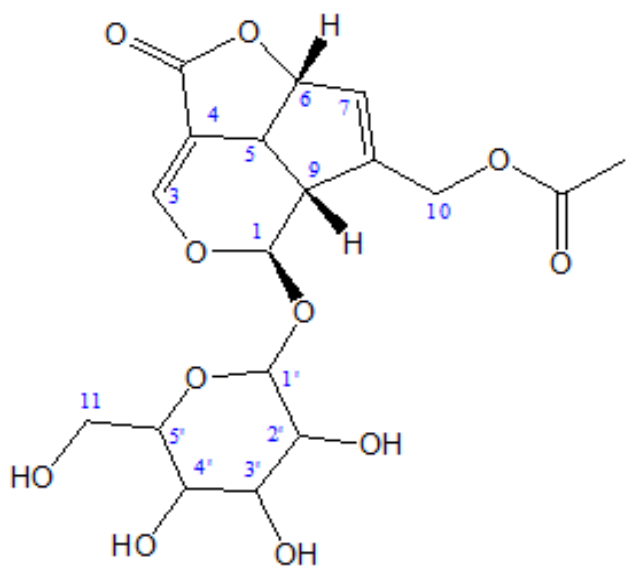

Figure 1. Structure of compound $\mathbf{1}$ (asperuloside) 


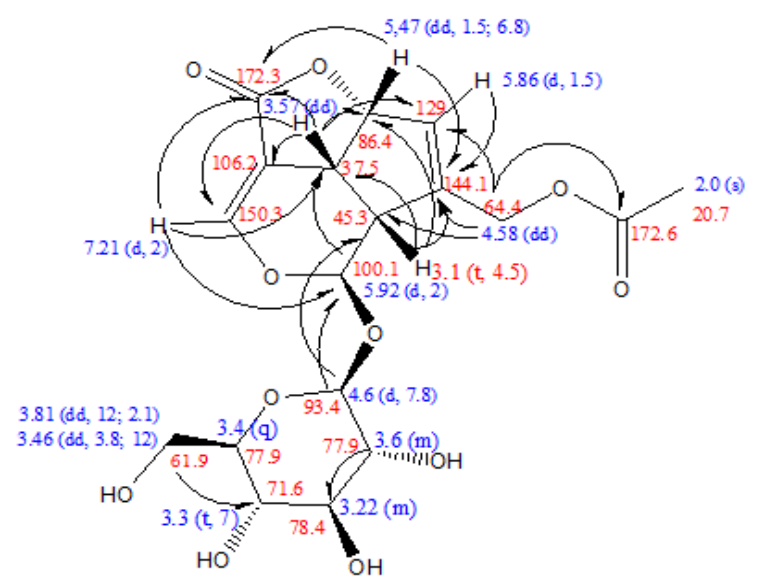

Figure 2. Summary of HMBC experiment of compound 1

the plates were air-dried. The solubilized bound dye with $200 \mu \mathrm{g} /$ well $10 \mathrm{mM}$ Tris base ( $\mathrm{pH} \mathrm{10)}$ for $5 \mathrm{~min}$ utes on a gyratory shaker. The measurement of Optical Density (OD) at $515 \mathrm{~nm}$ used ELISA plate reader (Tecan Mannedorf, Switzerland). Assay was performed in triplicates per extract. Antimycin A3 was used as positive control. Concentration of samples and control is $0.2-100 \mu \mathrm{g} / \mathrm{mL}$.

\section{RESULTS AND DISCUSSION}

$H$. corymbosa has shown cytotoxic activity to YMB-1 cell line with $\mathrm{IC}_{50}$ of $6.51 \mu \mathrm{g} / \mathrm{mL}$. After fractionation, the methylene fraction exhibits an $\mathrm{IC}_{50}$ of $2.75 \mu \mathrm{g} / \mathrm{mL}$. Our ethanol extract and its fraction in $n$ hexane, methylene chloride, and ethyl acetate have been previously reported to be inhibitory to breast cancer T47D cell line [13], with $\mathrm{IC}_{50}$ of $9.63,33.45,54.59$ and $52.58 \mu \mathrm{g} / \mathrm{mL}$, respectively.

We were able to purify the active compound that showed strong activity to inhibit both YMB-1 and HL60 with IC $_{50} 0.7$ and $11.0 \mu \mathrm{g} / \mathrm{mL}$, respectively, and its similar to standard. The compound has no activity against KB carcinoma cell line. For control standard, we used antimycin A3, with strong cytotoxic to growth inhibition human breast cancer cell line YMB-1, human leukemia cell line HL60 and KB with $\mathrm{IC}_{50}$ value of $0.3,1.7$ and $2.9 \mu \mathrm{g} / \mathrm{mL}$, respectively. Furthermore, it was identified by $1 \mathrm{D}$ and $2 \mathrm{D}$ NMR experiments data.

From ${ }^{1} \mathrm{H}$ NMR spectra of compound 1 (see Table $1)$, there were 16 signals present. Methyl proton was found at $\delta_{\mathrm{H}} 2.0$ ( $\left.\mathrm{s}, \mathrm{CH}_{3} \mathrm{CO}_{-}\right)$and indicated as acetyl group substituent. There were also two methylene and ten methine groups on the spectra. The methylene group which were found at $\delta_{\mathrm{H}} 4.58(\mathrm{dd}, 12.3 ; 7.8 \mathrm{~Hz})$ and $3.82(\mathrm{dd}, 12 ; 2.1 \mathrm{~Hz}), 3.42(\mathrm{dd}, 12 ; 3.8 \mathrm{~Hz})$ were suggested to be connected with an oxygenated group and has geminal coupling. Meanwhile the methine groups at $\delta_{\mathrm{H}} 3.2-3.6$ suggested to be connected with $-\mathrm{OH}$ groups, and indicated the presence of glucosyl group. It was supported by the presence of anomeric proton $\left(\mathrm{H}-1^{\prime}\right)$ at $\delta_{\mathrm{H}} 4.60(\mathrm{~d}, 7.8 \mathrm{~Hz})$. The olefinic group that more deshielded than others that were found at $\delta_{\mathrm{H}} 7.21(\mathrm{~d}, 2 \mathrm{~Hz})$ suggested as proton on $\mathrm{sp}^{2}$ carbon that also linked with an oxygen atom.

Inspection of ${ }^{13} \mathrm{C}$ NMR spectra revealed about 18 signals. Methyl signal that were present at $\delta_{\mathrm{H}} 2.0(\mathrm{~s})$, was easily determined as carbon at $\delta_{\mathrm{C}} 20.7$. Two carbonyls, and two quaternary $\mathrm{sp}^{2}$ carbon also present at $\delta_{\mathrm{C}} 172.3,172.6,144.1$ and 106.1 respectively. Four oxygenated methine carbons were signaled of $\delta_{\mathrm{C}} 71.6$ to 78.4 (non-anomeric carbon), and $\delta_{\mathrm{C}} 93.4$ (anomeric carbon). Methine carbons at $\delta_{\mathrm{C}} 93.4$ and $100.1 \mathrm{ex}-$ pected to have deshielding effect and suggested to be linked with two oxygen atom. By exposure of ${ }^{13} \mathrm{C}$ NMR, we suggested that it has monoterpene and glucopyranosyl basic skeleton. The basic skeleton of monoterpene was from ten carbon of one methylene $\mathrm{sp}^{3}$, two quaternary $\mathrm{sp}^{2}$ carbon, two methine $\mathrm{sp}^{3}$, two methine $\mathrm{sp}^{2,}$ two oxygenated methine $\mathrm{sp}^{3}$, and one carbonyl $(\mathrm{C}=\mathrm{O})$. Meanwhile, $\mathrm{CH}_{3} \mathrm{C}=\mathrm{O}$ groups suggested as substituent in monoterpene skeleton. The glucopyranosyl ring was presented by three non-anomeric carbons that also came from methine group, two anomeric carbon, and methylene groups which attached with hydroxyl group respectively. The methylene group from glucopyranosyl ring was presented by proton of $\delta_{\mathrm{H}} 3.8(\mathrm{dd}) ; 3.41(\mathrm{dd})$. It confirmed well in HMBC spectra by correlation of the proton with nonanomeric carbon at $\delta_{\mathrm{C}} 71.6(\mathrm{C}-4$ ') . Meanwhile, position of anomeric carbon of C-1 at $\delta_{\mathrm{C}} 93.4$, was showed by the correlation with anomeric proton at 4.6 (d) (See Table 2).

Construction of iridoid skeleton from monoterpene was started from the methine proton of $\delta_{\mathrm{H}} 5.92(\mathrm{H}-1$, $\mathrm{d}, 2 \mathrm{~Hz}$ ). By using HMBC spectra, the proton of $\mathrm{H}-1$ had a correlation with carbon of $\delta_{\mathrm{C}} 45.3$ (C-9) and 37.5 (C-5). Correlation between proton of $\mathrm{H}-9$ at $\delta_{\mathrm{H}}$ $3.1(\mathrm{~m})$ with carbon of $\delta_{\mathrm{C}} 37.5,86.4$, and 144.1 within two or three bond distance suggested that the carbons at position of C-5, C-6 and C-8 respectively. For proton of $\mathrm{H}-5(3.57, \mathrm{~m})$ which have correlation with carbon of $\delta_{\mathrm{C}} 150.3(\mathrm{C}-3), 106.3(\mathrm{C}-4), 172.3(\mathrm{C}=\mathrm{O}), 86.4$ (C-6) and 129.0 (C-7) confirmed the iridoid skeleton. Correlation between methylene proton $(\mathrm{H}-10)$ with the carbonyl of $\delta_{C} 172.6$ suggested that it adjacent to the carbonyl. So finally, we suggested the position of the 
methyl of $\delta_{\mathrm{H}} 2.0(\mathrm{~s})$ is also adjacent to the carbonyl of $\delta_{\mathrm{C}} 172.6$ due there is no other empty carbon space to be attached. The glucocyl group was located in C-1 based on the presence of long-range coupling between $\mathrm{H}-1$ at $\delta_{\mathrm{H}} 4.6(\mathrm{~d})$ to at $\delta_{\mathrm{C}}$ 100.1. The detailed HMBC experiment is summarized in Figure 1. The structure above is similar and in the agreement with asperuloside as showed in Figure $2[6,14,15]$.

\section{CONCLUSIONS}

The ethanol extract and methylene chloride fraction of $H$. corymbosa L. are prospective as a potential for anticancer, to growth inhibition to YMB-1 cell line with each $\mathrm{IC}_{50}$ value is 6.51 and $2.75 \mu \mathrm{g} / \mathrm{mL}$. A lead compound asperuloside also shown high biological activity to growth inhibition against to YMB-1 and HL60 cell line with $\mathrm{IC}_{50}$ is 0.7 and $11.0 \mu \mathrm{g} / \mathrm{mL}$.

\section{ACKNOWLEDGMENT}

Authors express their sincere thanks to Research Centre for Chemistry-Indonesian Institute of Science (LIPI) and the Japan Society for the Promotion of Science (JSPS) Japan, for support by Grants for Scientific Research. and permitting to carry out the research work. We wish to thank, Prof. Hideo Iio and Dr. Akira Ogita from Osaka City University, Osaka Japan for measurement NMR spectrum and biological assay.

\section{REFERENCES}

1. Sirait N (2015) Potensi rumput mutiara (Hidyotis corymbosa) sebagai antikanker. Warta Penelitian dan Pengembangan Tanaman Industri. 20(3): 11-13.

2. Sivapraksam SSK, Karunakaran K, Subburaya U, Kuppusamy S, Subashini TS (2014) A review on phytochemical and pharmacological profile of Hedyotis corymbosa Linn. Int. J. Pharm. Sci. Rev. Res. 26(1): 320-324.

3. Ahmad R., Ali AM, Israf DA, Ismail NH, Saari K, Lajis $\mathrm{NH}$ (2004) Antioxidant, radical-scavenging, anti-inflammatory, cytotoxic and antibacterial activities of methanolic extracts of some Hedyotis species. Life Sciences. 76: 19531964.
4. Liou WC, Lin YC, Lin YM, Chen FC (1979) N-Benzoyl- $L$ phenylalanyl- $L$-phenylalaninol acetate from Hedyotis corymbosa (L.) Lam. Chemistry. (3): 72-73

5. Ho TI, Chen GP, Lin, YC, Chen FA (1986) An anthraquinone from Hedyotis diffusa. Phytochemistry. 25(8): 1988-1989.

6. Jiang W, Kuang LS, Hou AJ, Qian M,L JZ (2007) Iridoid glycosides from Hedyotis corymbosa. Helvetica Chimica Acta. 90(7): 1296-1301.

7. Chinese Patent Application (2014) Traditional chinese medicine composition for treating stomach cancer, application and preparation. CN $103585514 \mathrm{~A}$.

8. Chen YH, Chang FR, Wu CC, Yen MH, Liaw CC, Huang HC, Kuo YH, Wu YC (2006) New cytotoxic 6-oxygenated 8,9-dihydrofurocoumarins, hedyotiscone A-C, from Hedyotis biflora. Planta Med. 72:75.

9. Zhao JF, Yuan QM, Yang XD, Zhang HB, Li L (2005) Two new iridoid glycosides from Hedyotis tenelliflora Blume. Helv. Chim. Acta. 88: 2532-2536.

10. Ahmad R, Shaari K, Lajis NH., Hamzah AS, Ismail NH, Kitajima M (2005) Anthraquinones from Hedyotis capitellata. Phytochemistry. 66: 1141.

11. Jiangsu College of New Medicine (1977), in HA Dictionary of the Traditional Chinese Medicines I. Shanghai Scientific and Technical Publishers, Shanghai. p. 535.

12. Sadasivan S, Latha PG, Sasikumar JM, Rajashekaran S, Shyamal S, Shine VJ (2006) Hepatoprotective studies on Hedyotis corymbosa (L.) Lam. J. Ethnopharmacology. 106: 245-249.

13. Andriyani R, Risdian C, Udin Z (2011) Cytotoxicity Assay from Fractions of Hedyotis corymbosa Extract Against Breast Cancer Cell Line T47D. Indonesian J. Cancer Chemoprevention. 2(1): 182-186.

14. Lee JH, Ku CH, Baek NI, Kim SH, Park HW, Kim DK (2004) Phytochemical constituents from Diodia teres. Arch. Pharm. Res. 27(1): 40-43.

15. Peng JN, Feng XZ, Peng XTL (1998) Iridoids from Hedyotis hedyotidea. Phytochemistry. 47(8): 1657-1659.

16. Jae HL, Chung HK, Nam IB, Sung HK, Hee WP, Dae KK (2004) Phytochemical Constituents from Diodia teres. Arch Pharm Res. 27(1): 40-43. 